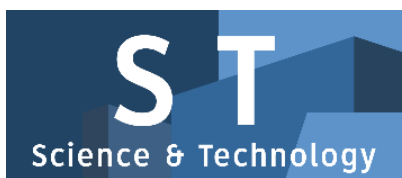

PAPER - OPEN ACCESS

\title{
Analisis Kualitas Produk Minuman Guna Meningkatkan Performansi Jumlah Produksi Dengan Metode Fmea (Failure Mode And Effects Analysis)
}

$\begin{array}{ll}\text { Author } & : \text { Listiani Nurul Huda } \\ \text { DOI } & : 10.32734 / \text { st.v1i2.292 } \\ \text { Electronic ISSN } & : 2654-7082 \\ \text { Print ISSN } & : 2654-7074\end{array}$

Volume 1 Issue 2 - 2018 TALENTA Conference Series: Science \& Technology (ST)

\section{(ㄷ) $(1)$}

This work is licensed under a Creative Commons Attribution-NoDerivatives 4.0 International License.

Published under licence by TALENTA Publisher, Universitas Sumatera Utara
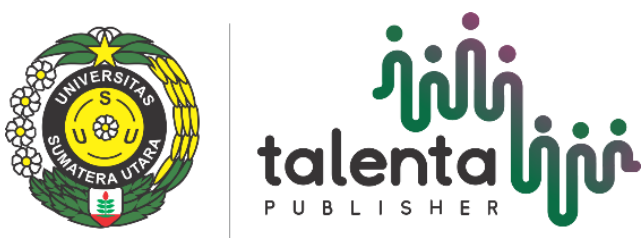


\title{
Analisis Kualitas Produk Minuman Guna Meningkatkan Performansi Jumlah Produksi Dengan Metode Fmea (Failure Mode And Effects Analysis)
}

\author{
Listiani Nurul Huda ${ }^{\text {a* }}$ \\ ${ }^{a}$ Universitas Sumatera Utara, Program Studi Teknik Industri
}

lnurulh@gmail.com

\begin{abstract}
Abstrak
Permasalahan produk cacat menjadi hal yang sangat penting untuk segera diatasi karena dapat menimbulkan kerugian. Produk yang cacatadalahsumberutamapemborosan salah satu penyebabnya akibat proses produksi yang dijalankan tidak sesuai prosedur operasi seperti yang diamati pada salah satu perusahaan penghasil botol minuman sirup. Pada proses sterilisasi botol sering terjadi produk cacat seperti keretakan, sompel bagian atas botol, pecah bagian bawah dan pecah keseluruhan bagian botol. Nilai kecacatan botol dapat mencapai sekitar $10 \%$ dari jumlah produksi sehingga mengakibatkan jumlah produksi perusahaan menjadi menurun. Penelitian ini dilakukan untuk mengetahui faktor-faktor apa yang mengakibatkan sering terjadi kecacatan botol. Proses identifikasi potensial kecacatan dilakukan dengan metode Failure Mode and Effect Analysis (FMEA) yang akan menentukan Nilai Resiko Prioritas (RPN) yang merupakan perkalian antara nilai keparahan (severity), kejadian (occurence), dan deteksi (detection). Dari hasil pengamatan diperoleh jenis kecacatan paling dominan pada proses sterilisasi botol adalah retak botol, faktor penyebab kerusakan botol yang disebabkan oleh operator yang kurang konsentrasi dan resiko kegagalan/kecacatan faktor penyebab kecacatan terbesar dalam nilai RPN (Risk Priority Number) sebesar 245. Hal ini mengindikasikan bahwa harus dilakukan penanganan untuk memperkecil kemungkinan terjadinya kecacatan dan dampaknya serta pengendalian deteksinya khusus bagi operator sterilisasi botol. Bentuk penanganan ditentukan oleh kepala tim atau oleh manajemen antara lain melalui inspeksi ketat terhadap pekerja.
\end{abstract}

Keywords: produk cacat; FMEA; RPN; Sterilisasi

\section{Latar Belakang Permasalahan}

Kualitas produk merupakan aspek penting yang sangat berpengaruh terhadap produktivitas suatu perusahaan. Penelitian ini dilakukan pada perusahaan yang bergerak dalam bidang pembuatan minuman. Pada proses Sterilisasi botol minuman sering terjadi kerusakan produk, seperti keretakan, sompel bagian atas botol, pecah bagian bawah dan pecah keseluruhan bagian botol. Keseluruhan kerusakan botol ini biasanya terjadi $\pm 10 \%$ selama kegiatan produksi berlangsung sehingga mengakibatkan jumlah produksi perusahaan menjadi menurun. Penelitian ini 
dilakukan untuk mengetahui faktor-faktor apa saja yang mengakibatkan sering terjadinya kerusakan botol. Proses identifikasi potensial kerusakan tersebut dapat dilakukan dengan metode Failure Mode and Effect Analysis (FMEA). FMEA menurut Gasperz (2002) adalah prosedur identifikasi dan pencegahan suatu mode kerusakan yang disebabkan kegagalan dalam desain atau kondisi diluar batas spesifikasi yang telah ditetapkan dan dapat menyebabkan kegagalan fungsi produk. Studi yang dilakukan oleh Mahmood Shafiee (2014) bahwa FMEA banyak digunakan produsen perakitan turbin untuk menganalisis, mengevaluasi dan memprioritaskan potensi kegagalan. Hasil studi ini merupakan faktor-faktor yang menyebabkan kegagalan tertinggi perakitan turbin adalah sfesifikasi bahan yang berbeda. Studi yang dilakukan Michal Sasiadek (2014) menyajikan metode FMEA untuk identifikasi cacat desain, tahap pembuatan dan penilaian kehandalan produk yang dirancang yaitu mesin pompa air. Hasil studi ini adalah didapat prioritas penyebab masalah kecacatan produk pompa air adalah rancangan struktur yang sangat buruk. Hal yang perlu dilakukan adalah menganalisis kegagalan yang paling dominandan mencari kemungkinan factor penyebab timbulnya kerusakan pada botol sirup kurnia dalam Cause and Effect Diagram dan mengidentifikasi penyebab kerusakan botol minuman terbesar dalam nilai RPN (Risk Priority Number) dengan menggunakan metode FMEA untuk kemudian diranking mulai dari nilai RPN terbesar hingga terkecil.

\section{Metodologi Penelitian}

\subsection{Structure}

Penelitian dilakukan pada lantai pabrik salah satu perusahaan manufakturing yang bergerak dalam pembuatan minuman botol berupa sirup. Pengamatan dilakukan terhadap hasil produksi botol sirup selama sebulan waktu pengamatan.

\subsection{Structure}

Prosedur penelitian yang digunakan dalam penelitian ditunjukkan pada Gambar 1 di bawah.

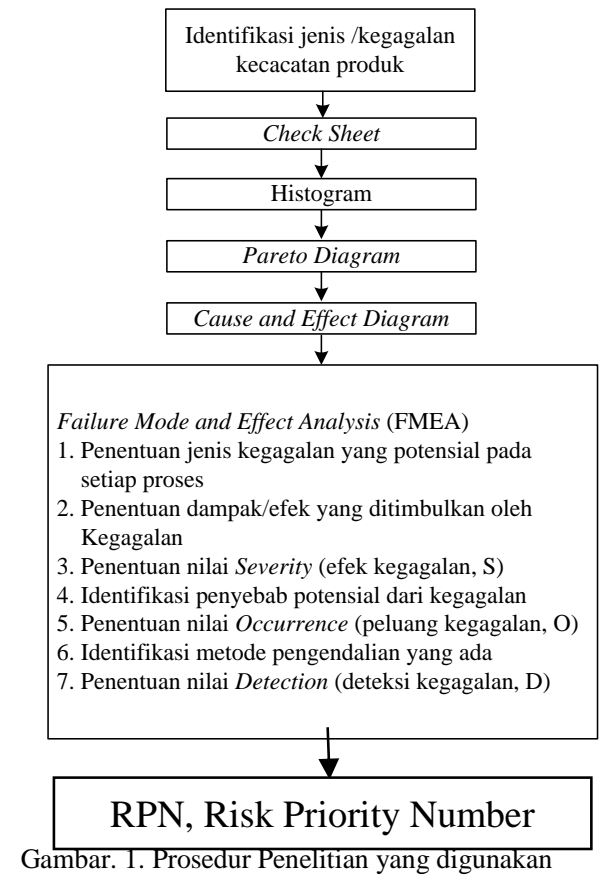




\subsection{Menghitung Nilai RPN (Risk Priority Number)}

RPN atauRisk Priority Number, yaituangka yang menyatakan skala prioritas terhadap resiko kualitas yang digunakan untuk panduan dalam melakukan tindakan perencanaan. RPN merupakan hasil perkalian dari severity (S), occurrence $(\mathrm{O})$ dan detection (D).

$$
\mathrm{RPN}=\mathrm{S} \times \mathrm{O} \times \mathrm{D}
$$

Angka RPN berkisardari 1 hingga 1000, di mana semakin tinggi nilai RPN, maka proses semakin beresiko untuk menghasilkan produk denganspesifikasi yang diinginkan.

\section{Hasil dan Pembahasan}

Berdasarkan hasil pengamatan di lapangan diperoleh bahwa botol akan mengalami rusak terbanyak pada stasiun kerja sterilisasi. Terdapat 4-jeniskerusakanbotol yang terjadiselama proses sterilisasibotolyaitu: kerusakan retak botol, kerusakan sompel bagian atas botol, kerusakan pecah bagian bawah botol, kerusakan pecah keseluruhan botol seperti ditunjukkan pada Gambar 2

botol, kerusakan pecah keseluruhan botol seperti ditunjukkan pada Gambar 2.
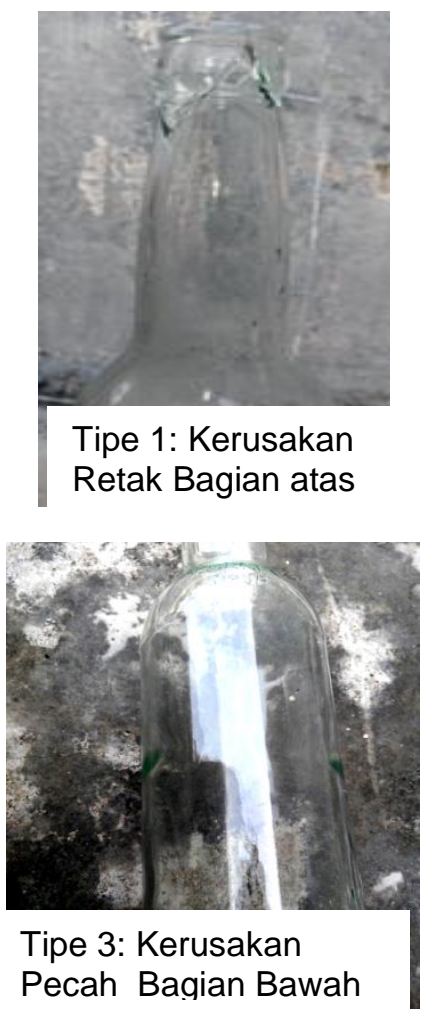

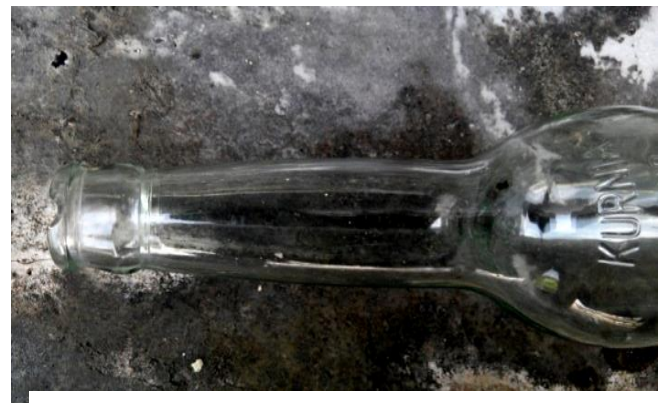

Tipe 2: Kerusakan Sompel Bagian Atas

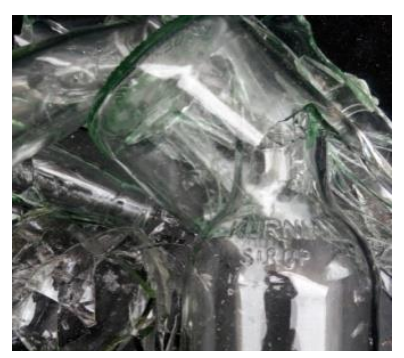

Tipe 4: Kerusakan Pecah Keseluruhan

Gambar 2 . Jenis-Jenis Kerusakan 
Dari gambar 2 tersebut dapat diketahui bahwa kondisi kecacatan botol dapat disebabkan karena 4-jenis kerusakan yang terbagi atas kerusakan sebagian atau keseluruhan. Keempat jenis kerusakan tersebut adalah retak bagian atas, sompel bagian atas, pecah bagian bawah dan adalah lebih banyak dibandingkan dengan pecah keseluruhan. Walaupun kerusakan hanya disebabkan bagian kecil dari botol seperti retakan pada botol hal ini sudah dianggap sebagai cacat pada botol dan botol tidak dapat digunakan. Adapun rekapitulasi kerusakan botol pada setiap jenis kerusakan ditunjukkan pada Tabel 1 dan Gambar 2.

Tabel 1. Rekapitulasi Data Pengamatan Kerusakan Botol pada Stasiun Sterilisasi

\begin{tabular}{|c|c|c|c|c|c|}
\hline \multirow[b]{2}{*}{ Pengamatan } & \multicolumn{4}{|c|}{ Jenis Kecacatan (Unit) } & \multirow[b]{2}{*}{ Jumlah } \\
\hline & $\begin{array}{c}\text { Tipe 1: Retak } \\
\text { bagian atas }\end{array}$ & $\begin{array}{l}\text { Tipe 2: Sompel } \\
\text { bagian atas }\end{array}$ & $\begin{array}{l}\text { Tipe 3: Pecah } \\
\text { bagian bawah }\end{array}$ & $\begin{array}{l}\text { Tipe 4: Pecah } \\
\text { keseluruhan }\end{array}$ & \\
\hline 2 & 285 & 389 & 421 & 114 & 1.209 \\
\hline 3 & 172 & 363 & 340 & 58 & 933 \\
\hline 5 & 253 & 360 & 397 & 82 & 1.092 \\
\hline 6 & 337 & 448 & 385 & 132 & 1.302 \\
\hline 7 & 277 & 426 & 423 & 106 & 1.232 \\
\hline Total & 1.746 & 2.710 & 2.677 & 663 & 7.796 \\
\hline
\end{tabular}

Tabel 1 menunjukkan rata-rata perjam tingkat kecacatan botol yang terjadi untuk retak sebagian (retak dan sompel) adalah sebesar 7.133 unit per jam atau 1.019 unit per jam sedangkan cacat secara keseluruhan adalah sebesar 663 unit per atau 95 uni per jam. Hal ini mengindikasikan bahwa tingkat kecacatan botol kemungkinan disebabkan oleh kegiatan parsial yang dilakukan tidak sesuai dengan SOP pekerjaan. Gambar 2 menunjukkan grafik sebaran rata-rata kerusakan botol untuk 7 kali replika pengamatan.

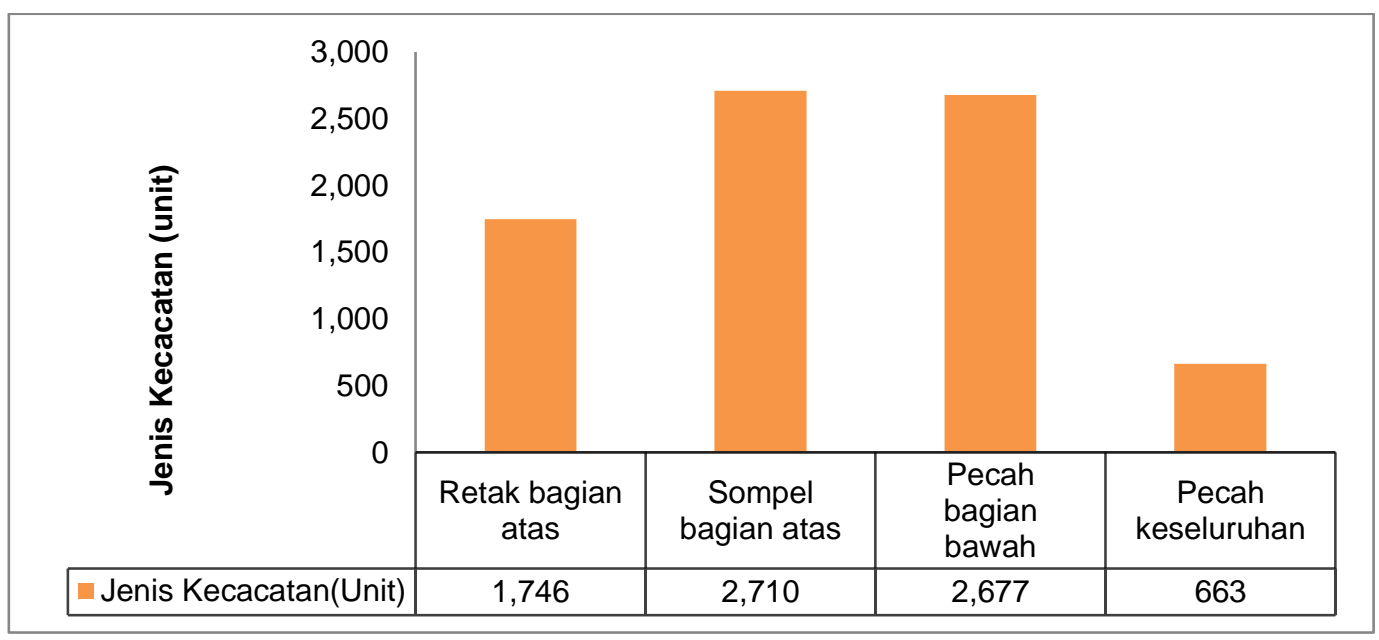

Gambar 2. Grafik Jumlah Kecacatan per Jenis Cacat di Bagian Sterilisasi 
Dari gambar 2 di atas mengindikasikan bahwa diagram yang terbentuk cenderung membentuk kurva normal dimana sisi miring terletak pada bagian kerusakan akibat retak bagian atas dan pecah keseluruhan. Sedangkan puncak kerusakan pada pola distribusi normal terletak pada sompel bagian atas diikuti pecah bagian bawah. Hal ini mengindikasikan bahwa sebaiknya perbaikan diarahkan pada kedua kerusakan ini. Berdasarkan data pada gambar 2 diperoleh persentase masing-masing kerusakan seperti ditunjukkan pada Tabel 2.

Tabel 2. Jumlah kerusakan botol pada proses sterilisasi.

\begin{tabular}{clccc}
\hline No. & Jenis Kecacatan & Total & Persentase (\%) & Kumulatif (\%) \\
\hline 1. & Retak & 1.746 & $22 \%$ & $22 \%$ \\
2. & Sompel bagian atas & 2.710 & $35 \%$ & $57 \%$ \\
3. & Pecah bagian bawah & 2.677 & $34 \%$ & $91 \%$ \\
4. & Pecah keseluruhan & 663 & $9 \%$ & $100 \%$ \\
\hline & Jumlah & 7.796 &
\end{tabular}

Berdasarkan histogram, jumlah kecacatan terbesar adalah pada jenis sompel bagian atas dengan data sebanyak 35 $\%$ danjumlah kerusakan terkecil adalah pada kerusakan pecah keseluruhan sebanyak 9\%. Sebaiknya perbaikan dilakukan pada bagian kerusakan yang terbanyak yaitu sompel bagian atas.

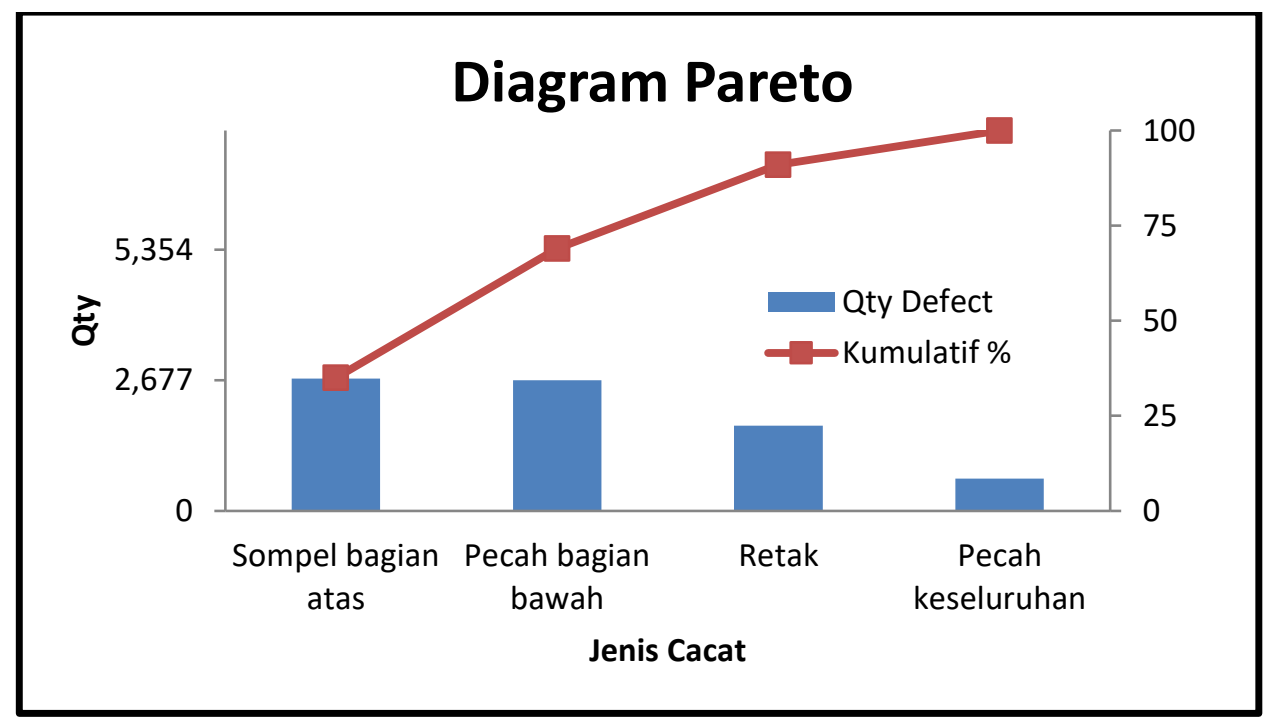

Gambar 3. Diagram Pareto Kerusakan Botol Minuman pada Proses Sterialisasi

Berdasarkan aturan pareto 80 - 20 diidentifikasikan sebagai permasalahan yang timbul pada kecacatan dan yang memiliki persentase kumulatif di bawah $80 \%$ yang harus dianalisis lebih lanjut. Seperti dibahas di atas bahwa kerusakan terbanyak adalah pada sompel bagian bawah. Permasalahan diidentifikasi menggunakan Cause dan Effect Diagram dan dianalisa menggunakanFMEA yang dapat menentukan efek yang ditimbulkan akibat kegagalan, penyebab dari kegagalan serta kontrol yang dilakukan untuk mencegah terjadinya efek dari kerusakan terbanyak tersebut ditunjukkan pada Tabel 3. 
Tabel 3. Rekapitulasi FMEA untuk Kerusakan Sompel Bagian Bawah pada Proses Sterilisasi

\begin{tabular}{|c|c|c|c|c|c|c|c|c|c|c|c|}
\hline \multicolumn{2}{|c|}{$\begin{array}{c}\text { Part/Process Function \& } \\
\text { spesification }\end{array}$} & \multirow[t]{2}{*}{$\begin{array}{c}\text { Potensial } \\
\text { failure mode }\end{array}$} & \multirow{2}{*}{$\begin{array}{l}\text { Potensial } \\
\text { effect of } \\
\text { failure }\end{array}$} & \multirow[t]{2}{*}{$\mathrm{Sev}$} & \multirow{2}{*}{$\begin{array}{c}\text { Potensial } \\
\text { Causes/Mechanism } \\
\text { failure }\end{array}$} & \multirow[t]{2}{*}{ Occ } & \multicolumn{2}{|c|}{ Current Control Design } & \multirow[t]{2}{*}{ Det } & \multirow[t]{2}{*}{ RPN } & \multirow[t]{2}{*}{$\begin{array}{c}\text { Recommended } \\
\text { Action }\end{array}$} \\
\hline & & & & & & & Prevention & Detection & & & \\
\hline \multirow[t]{3}{*}{ Operation } & Tidak teliti & $\begin{array}{c}\text { Kurang } \\
\text { memperhatikan } \\
\text { mesin }\end{array}$ & $\begin{array}{c}\text { Retak } \\
\text { Botol } \\
\text { Sirup } \\
\text { Kurnia }\end{array}$ & 7 & $\begin{array}{c}\text { Pekerja tidak } \\
\text { disiplin }\end{array}$ & 3 & $\begin{array}{c}\text { Memberikan } \\
\text { pengawasan } \\
\text { ketat pada } \\
\text { area kerja } \\
\text { tersebut }\end{array}$ & $\begin{array}{c}\text { Pemeriksaan } \\
\text { jumlah work } \\
\text { in process } \\
\text { yang cacat } \\
\text { pada area } \\
\text { kerja } \\
\text { tersebut }\end{array}$ & 3 & 63 & $\begin{array}{l}\text { Memilih } \\
\text { operator yang } \\
\text { disiplin }\end{array}$ \\
\hline & $\begin{array}{c}\text { Kurang } \\
\text { konsentrasi }\end{array}$ & $\begin{array}{c}\text { Kurang } \\
\text { memperhatikan } \\
\text { proses } \\
\text { pencucian }\end{array}$ & $\begin{array}{l}\text { Retak } \\
\text { botol } \\
\text { sirup } \\
\text { kurnia }\end{array}$ & 7 & $\begin{array}{c}\text { Pekerja mengobrol } \\
\text { dengan pekerja } \\
\text { lain yang berada } \\
\text { pada satu area } \\
\text { kerja }\end{array}$ & 7 & $\begin{array}{c}\text { Memberikan } \\
\text { pengawasan } \\
\text { yang ketat } \\
\text { pada area } \\
\text { kerja tersebut }\end{array}$ & $\begin{array}{l}\text { Memeriksa } \\
\text { metode } \\
\text { kerja }\end{array}$ & 5 & 245 & $\begin{array}{c}\text { Memilih } \\
\text { operator yang } \\
\text { disiplin dan } \\
\text { sangat } \\
\text { berkonsentrasi } \\
\text { dalam bekerja }\end{array}$ \\
\hline & $\begin{array}{l}\text { Settingan } \\
\text { mesin }\end{array}$ & $\begin{array}{l}\text { Kurang hati- } \\
\text { hati dalam } \\
\text { menempatkan } \\
\text { botol ke mesin }\end{array}$ & $\begin{array}{l}\text { Retak } \\
\text { botol } \\
\text { sirup } \\
\text { kurnia }\end{array}$ & 8 & $\begin{array}{c}\text { Pekerja tidak } \\
\text { disiplin dan hati- } \\
\text { hati }\end{array}$ & 5 & $\begin{array}{l}\text { Memberikan } \\
\text { SOP untuk } \\
\text { proses } \\
\text { tersebut }\end{array}$ & $\begin{array}{l}\text { Memeriksa } \\
\text { apakah } \\
\text { setiap botol } \\
\text { telah di } \\
\text { tempatkan } \\
\text { dengan } \\
\text { benar }\end{array}$ & 5 & 200 & $\begin{array}{c}\text { Memilih } \\
\text { operator yang } \\
\text { mampu } \\
\text { bekerja sesuai } \\
\text { SOP }\end{array}$ \\
\hline \multirow[t]{2}{*}{ Mesin } & $\begin{array}{c}\text { Kurangnya } \\
\text { maintenance }\end{array}$ & $\begin{array}{l}\text { Suhu proses } \\
\text { tidak sesuai } \\
\left(100^{\circ} \mathrm{C}\right)\end{array}$ & $\begin{array}{l}\text { Retak } \\
\text { botol } \\
\text { sirup } \\
\text { kurnia }\end{array}$ & 7 & $\begin{array}{c}\text { Tidak ada } \\
\text { maintetnance } \\
\text { berkala yang } \\
\text { dilakukan terhadap } \\
\text { mesin }\end{array}$ & 6 & $\begin{array}{l}\text { Melakukan } \\
\text { jadwal untuk } \\
\text { maintenance } \\
\text { terhadap } \\
\text { mesin }\end{array}$ & $\begin{array}{l}\text { Memeriksa } \\
\text { laporan } \\
\text { pelaksanaan } \\
\text { maintenance }\end{array}$ & 3 & 126 & $\begin{array}{c}\text { Perusahaan } \\
\text { melakukan } \\
\text { maintenance } \\
\text { sessuai dengan } \\
\text { jadwal yang } \\
\text { telah } \\
\text { ditentukan }\end{array}$ \\
\hline & $\begin{array}{l}\text { Umur mesin } \\
\text { yang telah } \\
\text { tua }\end{array}$ & $\begin{array}{c}\text { Produktivitas } \\
\text { mesin menurun }\end{array}$ & $\begin{array}{l}\text { Retak } \\
\text { botol } \\
\text { sirup } \\
\text { kurnia }\end{array}$ & 4 & $\begin{array}{c}\text { Beberapa part tida } \\
\text { berfungsi sebagai } \\
\text { mana mestinya }\end{array}$ & 4 & $\begin{array}{c}\text { Melakukan } \\
\text { jadwal untuk } \\
\text { pergantian } \\
\text { setiap part } \\
\text { pada mesin }\end{array}$ & $\begin{array}{l}\text { Memeriksa } \\
\text { laporan } \\
\text { hasil } \\
\text { penggantian } \\
\text { part mesin }\end{array}$ & 3 & 48 & $\begin{array}{c}\text { Perusahaan } \\
\text { melakukan } \\
\text { perbaikan dan } \\
\text { penggantian } \\
\text { part mesin } \\
\text { yang } \\
\text { tergolong } \\
\text { kondisi } \\
\text { mendekati } \\
\text { rusak }\end{array}$ \\
\hline \multirow[t]{2}{*}{$\begin{array}{l}\text { Lingkungan } \\
\text { kerja }\end{array}$} & Suhu tinggi & $\begin{array}{c}\text { Operator } \\
\text { terganggu } \\
\text { dalam proses } \\
\text { produksi }\end{array}$ & $\begin{array}{l}\text { Retak } \\
\text { botol } \\
\text { sirup } \\
\text { kurnia }\end{array}$ & 5 & $\begin{array}{l}\text { Operator kurang } \\
\text { konsentrasi }\end{array}$ & 3 & $\begin{array}{l}\text { Menambah } \\
\text { mesin } \\
\text { pendingin } \\
\text { ruangan kerja }\end{array}$ & $\begin{array}{c}\text { Meninjau } \\
\text { apakah } \\
\text { operator } \\
\text { bekerja } \\
\text { sesuai } \\
\text { prosedur }\end{array}$ & 2 & 30 & $\begin{array}{l}\text { Menambah } \\
\text { mesin } \\
\text { pendingin } \\
\text { ruangan kerja }\end{array}$ \\
\hline & $\begin{array}{c}\text { Tata letak } \\
\text { bentuk }\end{array}$ & $\begin{array}{l}\text { Banyak rak } \\
\text { botol yang } \\
\text { berserakan }\end{array}$ & $\begin{array}{l}\text { Retak } \\
\text { botol } \\
\text { sirup } \\
\text { kurnia }\end{array}$ & 7 & $\begin{array}{c}\text { Area kerja tidak } \\
\text { nyaman dan sempit }\end{array}$ & 7 & $\begin{array}{c}\text { Merapikan } \\
\text { area kerja } \\
\text { dengan } \\
\text { menempatkan } \\
\text { peralatan dan }\end{array}$ & $\begin{array}{c}\text { Memeriksa } \\
\text { area kerja }\end{array}$ & 4 & 196 & $\begin{array}{c}\text { Perusahaan } \\
\text { harus } \\
\text { melayout area } \\
\text { kerja }\end{array}$ \\
\hline
\end{tabular}


botol pada

tempatnya

Material

\begin{tabular}{ccccc}
\hline Botol yang & Kualitas botol & Retak & 8 & Pemeriksaan \\
tidak sesuai & yang diterima & botol & & terhadap botol \\
dengan & buruk & sirup & & harus lebih \\
standart & & kurnia & diperhatikan
\end{tabular}

$\begin{array}{ccc}\text { Melakukan } & \text { Memeriksa } \\ & \text { jadwal untuk } & \text { laporan } \\ \text { pemeriksaan } & \text { hasil } \\ \text { kualitas botol } & \text { pemeriksaan } \\ & \text { botol }\end{array}$
224
Perusahaan melaksanakan pemeriksaan sesuai dengan jadwal yang

telah

ditentukan

Berdasarkan Tabel 3 dapat diketahui bahwa dalam mengatasi kerusakan sompel bagian bawah diantisipasi berdasarkan RPN yang tertinggi sehingga akan menjadi focus utama untuk dilakukan perbaikan. Adapun analisis FMEA yang dilakukan diperoleh bahwa terjadi kurang konsentrasi pekerja dalam melakukan pekerjaan yang memiliki nilai RPN sebesar 245. Hal ini mengindikasikan bahwa harus dilakukan penanganan terhadap pekerja yang tidak konsentrasi bekerja tersebut antara lain memilih pekerja yang sesuai dengan jenis pekerjaan atau melakukan pengawasan yang ketat terhadap pekerja yang ada di stasiun sterilisasi.

\section{Kesimpulan}

1. Jenis kecacatan paling dominan pada proses sterialisasi adalah retak botol.

2. Faktor penyebab kerusakan botol disebabkan oleh pekerja .

3. Resiko kegagalan/kecacatan factor penyebab kecacatan terbesar dalam nilai RPN (Risk Priority Number) sebesar 245 adalah faktor operator karena kurang konsentrasi.

\section{Referensi}

[1] Badan Standarisasi (BSN). Standar Nasional Indonesia (SNI) 19-4370-2004

[2] Besterfield, Dale H. 1994. Quality Control. Edisi Keempat. London : Prentice Hall International.

[3] Dyadem Engineering Corporation. 2003. Guidelines for Failure Mode and Effects Analysis, For Automotive, Aerospace and General Manufacturing Industries. Kanada :

[4] Hidayat, Anang. 2007. Strategi Six Sigma, Peta Pengembangan Kualitas dan Kinerja Bisnis. Jakarta: PT Elex Media Komputindo.

[5] asiadek, Michal. 2014. Improving of Mechanical Engineering, Univerrsity of Zielona Poland.

[6] Shafiee, Mahmood. 2014. An FMEA-Based Risk Assessment Approach For Wind Turbine System : A Comparative Study of Onshore and Offshore. Institie for Energy and Resource Technology, Cranfield University United Kingdom.

[7] Tony, J.R. Arnold. 2008. Introduction to Material Management. Six Edition. 